\title{
Proposições da direção teatral para uma pedagogia com recursos do teatro de animação e/ou da dramaturgia da imagem ${ }^{1}$
}

Theatrical direction proposals for a pedagogy with resources of animation theater and/or image dramaturgy

Fabio Henrique Nunes Medeiros ${ }^{2}$ 


\section{Resumo}

O texto aborda como um ensaio-memorial proposições que foram elaboradas a partir de experiências teórico-práticas em âmbito de ensino-aprendizado formal e informal, bem como em processos de criação artística que se utilizaram de recursos do teatro de animação e/ou da dramaturgia da imagem como uma metodologia, norteada por três eixos: percepção, representação e composição.

Palavras-chaves: Pedagogia teatral; teatro de animação; dramaturgia da imagem

\section{Abstract}

This text approaches propositions that were drawn from theoretical and practical experiences in the context of formal and informal teaching-learning, as well as in processes of artistic creation that made use of resources of both animation theater and image dramaturgy as a methodology, guided by three axes: perception, representation and composition.

Keywords: Theater pedagogy; animation theater; image dramaturgy

\footnotetext{
1 Seria imprudente cunhar alguma definição categórica sobre esse termo em um artigo, uma vez que essa expressão é objeto de inúmeros estudos atuais que estão em ebulição e seguem diferentes abordagens e segmentos. Assim, por uma questão metodológica, para localizar a perspectiva dessa abordagem, utilizo-me dela primeiramente, entendendo dramaturgia como uma "escritura" teatral que se sustenta no tripé das matrizes das linguagens verbal, sonora e visual, e se operacionalizam pela manipulação desses códigos que se autopenetram, podendo deste modo ocupar diferentes relevos de acordo com cada proposição discursiva. Assim sendo, não está obrigatoriamente centrada no ator como senhor da manipulação desses códigos, isso porque as relações de subordinações ou não se devem à encenação. A dramaturgia da imagem ou da visualidade enfatiza o uso da imagem como principal fator da encenação. Isso não significa a exclusão por completo das demais matrizes da linguagem, uma vez que, como já dito, elas se autopenetram. Em termos práticos, a dramaturgia da imagem reconhece e explora as várias instâncias da cena como fatores dramáticos essências, tais como figurino, cenário, luz, sonoridade, espaço, os movimentos, os objetos, a projeção, etc. Entendo essas instâncias como linhas discursivas que fazem a tessitura da linguagem teatral e não apenas como colaboradoras de um discurso, mas como discurso em si.

2 Doutor em Artes Cênicas pela Universidade de São Paulo - USP, docente na Faculdade de Artes Paraná - FAP/UNESPAR e Diretor de Teatro.

fabiodeolinda@yahoo.com.br
} 
Os procedimentos aqui apresentados foram aplicados e desenvolvidos em cursos livres e workshops, em extensão universitária, na docência em ensino superior nos cursos de teatro, artes cênicas e cinema, e, principalmente na prática de direção teatral.

Essa proposição para formação segue três grandes eixos norteadores: Percepção (observação, princípios, atenção, sensibilização sensorial), Representação (meios, formas - como fazer) e Composição (linguagem, exercício de elaboração de um discurso artístico). Todas essas "modalidades" estão interligadas e sob o foco da figura da direção como mediadora na composição da cena, considerando que essa figura elabora e desenvolve procedimentos que culminam em um "produto" artístico.

Cabe frisar que, nessa perspectiva, a abordagem mais se alinha a uma visão semiótica da cena, na qual, entre outras coisas, observa a cena como uma máquina de sentidos que emanam de todas as camadas discursivas, sejam linguísticas ou não-linguísticas, de que todos os elementos produzem signos na cena, sem que necessariamente se estabeleça uma hierarquia ou subordinação. Isto é, entendendo que estabelecer uma hierarquia, como um paradigma, dentro dos elementos que compõem uma obra teatral pode reduzir e limitar o fator estruturante da linguagem teatral no seu aspecto polifônico. Essa subordinação pode e acontece, mas deve ser estabelecida pela encenação, e não por um modelo que, historicamente, em determinados períodos, esteve centrado no dramaturgo, no diretor ou no ator.

Pode-se dizer que o "teatro de atores" esteve, por muito tempo, preso a uma matriz verbal e sonora, devido a fatores históricos e culturais, o que pode ter limitado o desenvolvimento de aspectos da linguagem visual. Diferentemente ocorre no teatro de animação, que tem a matriz visual como parte de sua estrutura.

Além de dar cabo a esse entendimento, o recorte desse texto se direciona em observar o teatro de animação em relação à dramaturgia da imagem.

Sempre relutei em denominar o teatro de animação como um gênero do teatro, defendendo então reconhecê-lo como uma linguagem teatral autônoma e específica. Isso não qualifica ou desqualifica essa forma de expressão, mas demonstra um entendimento estrutural sobre ela, a partir de uma leitura da essencialidade dessa linguagem, portanto, fenomenológica.

O teatro de animação é uma linguagem que se aproxima veementemente das artes visuais, talvez até mais do que do próprio "teatro de atores". Essas ligações com a sintaxe visual estão num nível estruturante cujos percentuais de conexões são difíceis de mensurar, especialmente por estas serem internas. Contudo, é preciso admitir que ela está na raiz dessa linguagem.

O boneco é um ícone, signo de um personagem vivo, em geral de um personagem dramático. Concebido e realizado pelo homem, coisa ou objeto, ele é uma obra plástica cuja expressão artística depende de nosso olhar. O espaço cênico tem também um caráter plástico assim como o bonequeiro que se produz na rua com um boneco, sem empanada. Todos, à exceção do homem, são artificiais. Esta é a razão porque certos artistas qualificam o teatro de bonecos de teatro de artes plásticas animadas. (Jurkowski, 2000, p. 116)

A imagem é um elemento que alicerça a animação, pois a animação dá vida a algo que se vê, embora não apenas. Um exemplo prático disso é o teatro de pulgas, 
que anima o invisível, e mesmo assim requer a presença de um animador (imagem) que com seus movimentos e gestos (imagem) proporciona a animação, ou seja, o que se vê. É na imagem que se concentra a síntese dramatúrgica do teatro de animação. $O$ teatro de animação "é a arte da imagem e do movimento", "suas formas são símbolos" (Amaral, 1996, p. 245).

Recorrendo à etimologia, vemos que a palavra drama vem do grego, significando ação, e do latim [imago], que significa a representação visual de um objeto, que no grego é eidos, derivando a palavra ideia. Sendo assim, seria possível entender a palavra dramaturgia como uma espécie de agrupamento de ação-imagem-objeto-ideia? Seguindo uma lógica semântica de associação entre essas definições, pode-se pensar que a dramaturgia trata da ação da imagem a partir de uma ideia. "O drama não se escreve, o drama surge na cena [é um] conflito intersubjetivo [...] entre os diversos elementos cênicos: espaço, imagem, corpo e som" (Sanchez, 2002, p.38).

Estão na representação (imagem-ideia) as qualidades dramáticas, narrativas e puramente abstratas (sensações "múltiplas"). Portanto, considerando essa característica, essa abordagem vai discutir algumas formas de fazer e aprender o teatro de animação em relações com a dramaturgia da imagem.

Começo essa reflexão dizendo o óbvio, mas que nem é tão óbvio assim. A arte talvez seja a forma de expressão mais livre do ser humano, e é em nome da manutenção desta sua característica essencial de liberdade que enfatizo que a arte não deve ter manual. Ou seja, os procedimentos aqui levantados são apoiados tanto em formas consagradas, como também em adaptações muito vivas, uma vez que foram experimentadas no calor do fenômeno teatral (em salas de aulas com alunos de teatro, em montagens de espetáculos e no encontro com o público). Deste modo, essas proposições são experiências peculiares realizadas em determinados grupos para fins específicos, mas que podem servir como referência em algum processo artístico ou em ambientes pedagógicos.

Assim como muitos diretores e pedagogos de teatro costumam recorrer a folguedos e a brincadeiras populares, bem como a outras manifestações lúdicas para suas proposições, aqui também foi adotada essa recorrência, tanto diretamente da fonte da brincadeira popular como também por meio de vivências de workshops e oficinas. Contudo, nenhum dos jogos aqui revisitados foi realizado da maneira tradicional, tendo todos passado por inúmeras adaptações, de modo a enfatizar as questões que se objetivava desenvolver. Um exemplo explícito é o jogo "ZIP, ZAP", cuja versão mais conhecida é a de Augusto Boal, a qual foi utilizada como referência inicial.

Quando eu perguntava aos participantes se conheciam este jogo, sempre havia alguém que se manifestava afirmativamente. Nesse momento eu dizia: "Então esqueçam". Mesmo assim, começávamos o jogo como ele parece ser, para logo em seguida iniciar a propor as modificações. Essas mudanças eram tão grandes e possuíam objetivos tão específicos (desenvolver o FOCO pelo som, imagem e movimento) que quase não era possível reconhecer o jogo proposto inicialmente. Ou seja, partiu-se desse "jogo-marco-zero" para então atingir questões mais complexas do desenvolvimento da expressão do ator para uma percepção da animação. Nesta versão do exercício é possível trabalhar vários canais expressivos de comunicação. 
Mencionar esse exemplo serve para situar uma ação prática que percorre boa parte dessa proposição, não cabendo, infelizmente, descrever aqui todas as etapas e sequências dos jogos para sua aplicabilidade, servindo assim apenas para situar um procedimento recorrentemente adotado.

Um outro recorte dessa abordagem é contemplar o trabalho da manipulação estando o ator-manipulador visível ao público, entendendo que essa forma de animação além de ter se popularizado na contemporaneidade, exige ainda um exercício complexo na cena, pois expõe dois corpos à ação, além de entender o movimento como o signo mais complexo da cena, na qual o corpo do ator é, recorrentemente, intermediário na dinâmica dos demais corpos na composição com o espaço.

Essa proposta busca uma qualidade no treinamento desse corpo do ator aparente na cena, seja ele neutralizado ou não. Essa escolha se baseia na perspectiva de que o ator visível, em contraposição ao não visível, requer um trabalho em termos expressivos, exigindo assim outro grau de complexidade, pois expõe os "corpos na fronteira", especialmente por ele ter que lidar com um "corpo-morto" em oposição a um "corpo-vivo". Deste modo, as expressões desses corpos precisam estar bem demarcadas para a criação de um discurso. Não se pode ignorar que são dois corpos em cena, muitas vezes na função de expressar um único ser. Assim, para se tornar uma coisa crível, se instala a ambiguidade das presenças.

Em termos práticos, a partir do tripé PERCEPÇÃO, REPRESENTAÇÃO E COMPOSIÇÃO, foi elaborada a seguinte estrutura, com etapas a serem desenvolvidas, para contemplar os três eixos: $1^{\circ}$ - (Encontro com o invisível) - Série de exercícios de "extensão" da percepção: atenção, imaginação, escuta, e princípios técnicos de animação; 2 - (Do invisível para o visível) - Criação e construção de "personagem" ou seres elementares, como uma ideia (as características físicas e comportamentais ou apenas de sua vida) e sua materialização (seja essa matéria um boneco, uma forma abstrata, um objeto cotidiano, ou uma partitura de movimentos corporais); e 3ㅇ- (Experiência/elaboração poética) - Montagem de situações com elementos da animação (esteja no processo ou no "produto") que tenha um discurso artístico.

\section{Percepção}

A Percepção é o eixo mais explorado e desenvolvido, pois, nessa concepção, ela alicerça toda a prática da animação, bem como contribui para a formação do ator de modo geral. Trabalhar a percepção para animação ou para o ator parte da premissa que os códigos do teatro contemporâneo modificaram as instâncias dos signos emergentes da cena, desierarquizando o centro da linguagem teatral a determinado código ou função, seja do texto, da direção ou mesmo do ator.

Esse "novo" paradigma da linguagem teatral foi o que levou a pensar essa estrutura de ensino e treinamento. Pois essa proposta pretende, entre outras coisas, ativar os sentidos, para que a percepção dê vazão para outras percepções. Entre elas, a percepção da animação, que pode, ou não, ser usada para animação, embora tenha mais a ver com uma espécie de estado de percepção que permite o fantástico como fator real e não apenas como um elemento externo à realidade. O fantástico é entendido, genericamente, como aquilo que foge das leis da natureza, que transgride o mundo real. Mas, afinal, não é esse um dos principais movimentos da composição poética? 
Explorar a percepção do fantástico-imaginário corresponde a uma espécie de "desatrofia" social, nadando contra a corrente de extirpação do lúdico e do animismo em detrimento de uma lógica do real. Ou seja, é um movimento de reencontrar a infância, nos aspectos do lúdico e do animismo. Não só a infância, mas uma espécie de "primitivismo" ancestral. Nesse viés, a animação começa na percepção, nessa capacidade lúdica de atribuir outras naturezas às coisas, de criar analogias, e com isso qualidades poéticas. Esse movimento faz o ator perfurar a invisibilidade com veracidade, manipulando os vazios da cena e dando novos entendimentos sobre os códigos que o rodeiam.

A percepção da animação quer desenvolver o trabalho do animador, a partir de princípios técnicos e estéticos, seja de objetos, bonecos ou animação do invisível. Portanto, isso não serve apenas para a animação, mas também para o ator contemporâneo, que tem que lidar com inúmeras emergências da cena contemporânea, entre elas as questões de virtualidade. Nesse sentido, trabalhar a animação do invisível está também muito próximo do trabalho do mímico.

Alguns exercícios:

* Indicações quase universais

São indicações que podem ser utilizadas em quase todos os jogos, como uma espécie de acúmulo de ações, podendo-se acionar outras ações além daquelas propostas para cada jogo, sem que se exclua nenhuma de suas prerrogativas. Ou seja, além daquelas indicações do jogo em execução, esses indicativos universais podem ser acionados a qualquer momento, servindo como uma espécie de desafios e impulsos.

- Velocidades - De 1 a 7, sendo a 3 a mais próxima à cotidiana.

- Nível - 1 a 3 (Baixo, médio e alto, estabelecidos pela flexão dos joelhos)

- Uma palma - Para ou continua (Às vezes pode denominar a mudança de direção)

- Duas palmas seguidas - Pula

- Três palmas ou mais seguidas - Levanta um dos braços e diz "Piu" ou "Ai"

- "Coice!" - Dar um coice no ar.

- "Micro" ou "Macro" - "Micro" para se estabelecer um ponto fixo com o olhar e "macro" para um foco maior, disperso ou explorar o olhar periférico.

- "Mãozinha" - Levanta as mãos na altura da barriga e começa a mexer os pulsos e dedos como se tivesse digitando no ar. No comando de "mãozinha" novamente volta-se para aposição original.

- "Mão" - O olhar micro se direciona para as mãos.

- "Ponto zero" - Voltar para a posição original.

- "Terremoto" - Seria o caos, a mudança de posição de todos os participantes.

Como aquecimento e para que os participantes memorizem essas indicações, começamos com a clássica caminhada pelo espaço, sob a orientação básica de concentração, de acordar os sentidos, corpo alinhado, com base e atenção. Além disso, 
há a indicação de que a "pisada deve ser de ator", ou seja, que se busque um corpo não cotidiano, um corpo presente, mas ainda não expressivo também, que se estabeleça como um corpo intermediário, acordado para as ações (impulsos externos e internos).

Para os exercícios de deslocamento espacial, os comandos "micro" e "macro" funcionam bem, e nessas ocasiões, uma palma funde dois códigos: o de parar e o "micro" (achar um ponto fixo), para se deslocar até ele. Outra observação é que a mudança de direção, no ato de encontrar um ponto micro deve estar bem marcada pela seguinte sequência: Parar, olhar (com a cabeça inteira) e ir na direção.

* Quem puxa quem? - Esse exercício começa do modo proposto por Augusto Boal em Hipnotismo Colombiana ${ }^{3}$, mas vai ganhando novos objetivos e novas formas. Em duplas, um participante coloca a palma da mão numa distância de aproximadamente $10 \mathrm{~cm}$ do rosto do outro, criando assim uma espécie de forma magnética entre a mão e o rosto. A partir de então, como em uma hipnose, um começa a puxar o outro nessa posição, sem que o colega que está sendo puxado perca o controle dessa distância, acompanhando a condução estabelecida pela hipnose. É um exercício de manipulação, em que um manipula e o outro é manipulado. Esse jogo deve ter sido criado para o teatro de animação, pois coloca o artista em duas posições da manipulação, percebendo o movimento da manipulação por dois ângulos. Inúmeras e potentes são as variações desse jogo, mas não cabe descrevê-las aqui.

* Mãos num círculo virtual ${ }^{4}$ - Com três integrantes, tendo um espaço livre à frente do grupo, devendo os três se posicionar lada a lado. Sob o comando de uma palma externa ao trio, um deles sai dessa posição, dando dois passos para frente, posicionando as mãos, paralelas, à frente de seu corpo, colocando-as dentro de um círculo imaginário que flutua. A posição das mãos desse primeiro participante deve estar no limite desse círculo, estabelecendo assim o tamanho da circunferência do mesmo para os demais. Em seguida, sob o comando de novas palmas, o segundo participante sai da posição original e também preenche o círculo com as mãos e assim sucessivamente faz o terceiro. Quando todos tiverem preenchido o círculo, as palmas continuam indicando as saídas de posição para formação de novo circulo. O primeiro a sair não será, necessariamente, o primeiro que saiu no início do jogo, podendo-se mudar a ordem. O exercício continua até que todo o trajeto seja realizado. Uma observação fundamental é que todos devem manter continuamente o olhar para dentro do círculo.

Em uma variante desse exercício, repete-se toda a sequência, mas sem os comandos das palmas, devendo cada um começar a ação num estado de silêncio absoluto, e os três integrantes devem estar atentos ao jogo, entrando num acordo silencioso sobre quem irá começar. Os demais darão continuidade à sequência de preenchimento do círculo. Além disso, na medida em que forem colocando as mãos dentro do círculo, todos têm que emitir um som de suspiro. Na terceira rodada

\footnotetext{
${ }^{3}$ Esse exercício se encontra em BOAL, Augusto. Jogos para atores e não-atores.14ªed. Rio de Janeiro: Civilização Brasileira, 1998.

4 O primeiro contato com uma versão desse exercício foi na oficina O ator e a manipulação direta, ministrada pela Cia Catibrum, de Minas Gerais, durante um evento do Palco Giratório do SESC-PR em 2015.
} 
do exercício, se estabelece que o primeiro a colocar a mão dentro do círculo, fica responsável por segurar a "cabeça e quadril do boneco" imaginário, o segundo, os "braços" e o terceiro, as pernas.

O olhar de todos, que antes estava direcionado para dentro do círculo, deve ser agora ainda mais específico, focando-se a cabeça do "boneco". E isso se a personagem possuir "logus", razão ou consciência. Essa analogia serve para indicar, através do "micro-foco" na cabeça, que o boneco é um ser pensante, portanto, possuidor de alma.

Esse tipo de analogia, de enfatizar a cabeça em relação ao restante do corpo para figuras possuidoras de pensamento, é bastante recorrente em inúmeras "narrativas" das performances com bonecos, seja em manifestações das culturas tradicionais ou eruditas.

No caso de representações de seres apenas viventes ou elementares, sem logus, o foco não precisa estar diretamente na cabeça, mas todos os integrantes devem olhar para o mesmo ponto: vertebral, cabeça, quadril, etc. Isto se não se tratar de um ser híbrido.

* $A$ cruz ${ }^{5}$ - Se desenha uma cruz imaginária no chão, com quatro participantes se posicionando em cada extremo do desenho. Cada ponta da cruz tem uma função e os participantes que ocuparem essas posições devem executar suas respectivas ações. A ponta superior é a posição mais complexa, pois quem estiver nela deve olhar sempre para frente, para o participante que se encontra na base da cruz, e reproduzir seus gestos, como um espelho. Por sua vez, quem está na base da cruz não pode se deslocar, devendo seus gestos ser executados apenas nesse lugar. As duas outras pontas da cruz têm as seguintes funções: a do lado esquerdo deve fazer perguntas aleatórias para quem está na parte superior da cruz e a do lado direito deve dizer que está indo embora, de forma que quem estiver na parte superior tem que convencê-lo a não ir argumentando, tudo isso sem olhar para os lados, nem das perguntas nem da argumentação, apenas para frente.

Quem está na ponta da cruz trabalha vários sentidos concomitantemente, explorando uma espécie de decomposição dos sentidos da percepção. Ou seja, seu olhar está para frente recebendo os comandos da visão, enquanto sua audição está recebendo impulsos dos dois lados: no lado esquerdo, o lado das perguntas que devem ser respondidas sobre uma lógica aceitável e do lado direito, que é o lado da fala, onde se constrói argumentos, o sentido mais completo da linguagem humana. Os argumentos são conexões complexas da linguagem-pensamento, pois requer uma elaboração mais racional.

Ao comando externo de uma palma, a roda gira no sentido anti-horário, fazendo com que os participantes mudem deposição e troquem as funções. Além dessa intervenção externa, também, no decorrer do exercício, podem ser acrescentados alguns daqueles "indicativos quase universais". Que funcionam muito bem na perspectiva de atenção dos sentidos.

* Caminhada, mão que olha - É um exercício de caminhada que contempla especificamente a animação. Dessa forma, deve ser utilizado depois de uma série de exercícios de percepção. Pode ser tratado como um exercício de transição entre

${ }^{5}$ O contato com esse exercício se deu num workshop da Cia. Parlapatões de São Paulo, durante o Festival Cena Internacional de 2012 no Teatro Sérgio Cardoso na mesma cidade. 
os eixos percepção e representação. Inicia-se o exercício com todos caminhando livremente no espaço. Sob o comando da palavra "Olha", eles devem, dando continuidade à ação, encontrar o olhar de alguém. Quando isso acontecer, eles "grudam" esses olhares e na mesma velocidade e ritmo vão mudar de lugar entre eles, traçando um círculo no chão durante esse deslocamento. A distância e o ritmo entre os olhares devem se manter durante todo o círculo. Tendo este sido traçado, os participantes desgrudam os olhares e continuam a caminhada na velocidade anterior ao grudamento dos olhos.

Acrescenta-se ao exercício a palavra "Mão", que significa que cada um deve, continuando a caminhada, olhar para a própria mão e criar nela uma elevação (extremidade) com um ou mais dedos. É importante que nesse primeiro momento, no comando "mão", ela vá para uma posição acima da cabeça, para que o movimento do foco fique melhor demarcado. Novamente como comando da palavra "Olha", eles devem refazer a sequência de encontrar um "olhar", mas dessa vez com essas figuras das mãos. Assim, quem irá olhar são essas mãos para outras mãos, estabelecendo a mesma conexão da orientação inicial do exercício. Concluído o trajeto do círculo, as mãos voltam ao status de mão e a caminhada deve continuar na velocidade que o encontro dos olhares havia começado. Acrescenta-se a isso, noutra rodada, um suspiro da mão ao encontrar o olhar de outra mão.

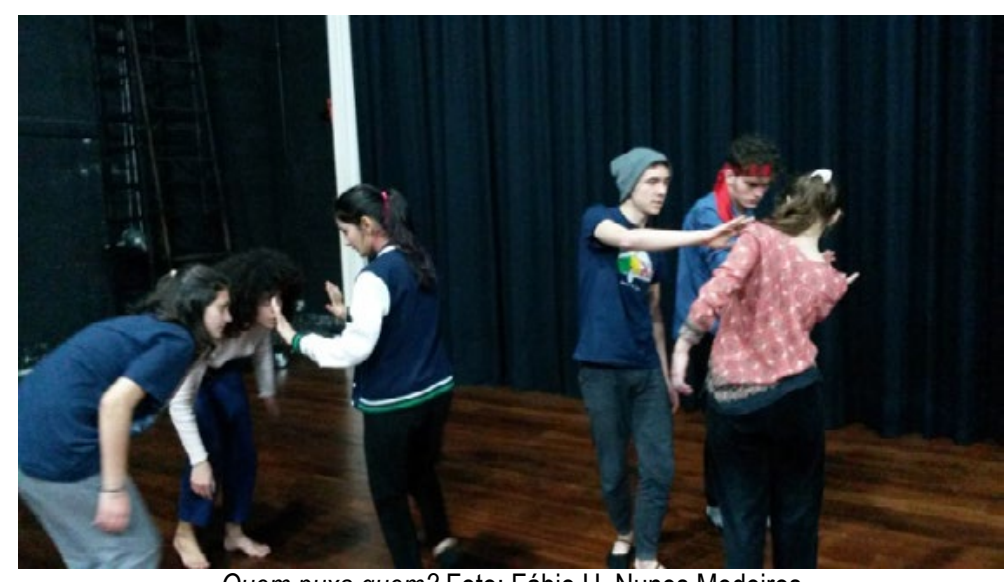

Quem puxa quem? Foto: Fábio H. Nunes Medeiros

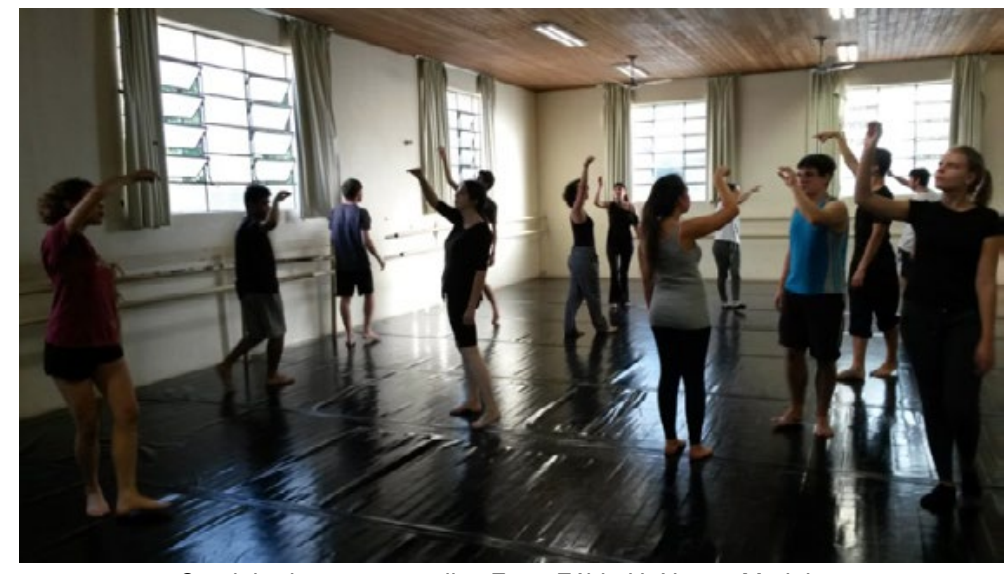

Caminhada, mão que olha. Foto: Fábio H. Nunes Medeiros

Todos esses jogos são mais complexos do que a descrição aqui apresentada, mas essas sínteses servem para ilustrar e dar uma visão global e prática do desenvolvimento dessa proposição. 
Além dos exercícios criados e adaptados, essa proposição teve também como referência alguns jogos de Jacques Lecoq, especialmente no que converge para o uso de máscaras. Isto por entender que o trabalho com máscaras possibilita uma dupla percepção sobre a animação, na qual o "estado de descolamento" da criação de um ser vivente, pode se expressar fora ou dentro do corpo. A máscara possibilita o ator habitar uma "forma-ser" em várias proporções, animando-a de dentro para fora ou de fora para dentro. Esses exercícios podem qualificar significativamente a animação.

\begin{abstract}
A máscara neutra é um objeto particular. É um rosto, dito neutro, em equilíbrio, que propõe a sensação física da calma. Esse objeto colocado no rosto deve servir para que se sinta o estado de neutralidade que precede a ação, um estado de receptividade ao que nos cerca, sem conflito interior. Trata-se de uma máscara de referência, uma máscara de fundo, uma máscara de apoio para todas as outras máscaras. Sob todas as máscaras, sejam expressivas ou da commedia dell'arte, há uma máscara neutra que reúne todas as outras. Quando o aluno sentir esse estado neutro do início, seu corpo estará disponível, como uma página em branco, na qual poderá inscrever-se a 'escrita' do drama. (Lecoq, 2010, p.69)
\end{abstract}

Essa possibilidade proposta pela máscara neutra de uma espécie de zeramento expressivo do corpo foi um dos primeiros motivos pelo qual recorremos a ela. $O$ "apagamento" das marcas expressivas do corpo possibilita a criação de um corpo "totalmente" construído, ou seja, um corpo poético, elaborado esteticamente.

\title{
Representação (Observação, Mimese, modos de fazer...)
}

Há imitação e imitação, alguns imitam por incapacidade, outros para ensaiar asas.

(Mário de Andrade)

Nesse eixo, a abordagem se aproxima mais das especificidades do teatro de animação, ou de animação de personagens, pois o enfoque já é a linguagem da animação em si. Essa fase ressalta as questões da representação da animação, e para tal a observação e a Mimese são fatores determinantes. Nesse quesito é importante recorrer à estrutura básica da análise semiótica: emissor, mensagem e receptor.

Assim sendo, faz-se necessidade do uso de um referente, como uma espécie de unidade mínima de significação ou unidade organizadora na função comunicativa. Um exemplo prático e exemplar da necessidade de um referente, portanto da representação e mimese, pode ser percebido num dos princípios do teatro de objetos, no qual se faz uma negação de alguns códigos da representação, uma vez que os objetos aludem a situações humanas ou a animais sob a forma de objetos. Deste modo, mesmo que haja a negação de alguns códigos de representação mais próxima do corpo antropomorfo ou zoomorfo reais, esses códigos estão desprovidos de suas fisicalidades e formas, mas a representação recorre aos códigos de suas ações através do referente. Ou seja, as ações dos objetos têm como referência os movimentos e comportamentos humanos e animais, mimetizando-os.

O inverso também nos serve como exemplo para o teatro de bonecos: quando a representação fiel à figura humana está expressa na fisicalidade ou na forma da 
figura, as ações e movimentos dos personagens ficam mais livres para seguir outras referências, entre elas a de objetos.

Quanto mais códigos forem diluídos no sistema de representação, mais abstrata fica a produção de sentido, devido à falta de referência. Assim, a função comunicativa vai entrando noutro nível de representação.

Para ilustrar esse eixo, vou descrever e analisar alguns exercícios, também como forma de tornar essa proposição mais concreta. Frisando ainda que esses exercícios que fazem pequenos contatos com a materialidade podem ser tratados como exercícios de transição entre os eixos percepção e representação, de forma que eles podem ter essas duas perspectivas.

Um dos primeiros exercícios propostos na perspectiva de representação é o jogo que denomino de Bonecos de nós. Essa denominação se dá pelo fato de os "bonecos" serem representações humanas feitas com nós em tecidos.

* Bonecos de nós ${ }^{6}$ - Espalha-se no chão do espaço vários pedaços de tecido que tenham aproximadamente um metro de comprimento. Os participantes começam uma caminhada, tendo inicialmente apenas dois propósitos: desviar dos tecidos e utilizar o olhar macro, explorando o olhar periférico, cujo objetivo é conhecer o espaço dentro daquela disposição. Sob um indicativo, podendo este ser a retirada de uma música de fundo ou um comportamento de coro ${ }^{7}$, cada três participantes devem se direcionar para algum dos tecidos espalhados, agora com o olhar focado no tecido, para em seguida fazer nele fazer cinco nós, representado as cinco extremidades do corpo humano (cabeça, pernas e braços). A partir de então, faz-se uma improvisação com a figura.

É importantíssimo frisar que todas as ações devem ter continuidade e seguirem esta sequência: deslocamento até os tecidos, realização dos nós, levantada do boneco buscando seu eixo, proposições improvisadas, retorno da figura numa trouxa de tecido e, por fim, retomada da caminhada com o olhar macro.

Esse exercício tem inúmeras variações importantes e deve ser realizado como treinamento contínuo, uma vez que pode contribuir para o desenvolvimento de várias questões da cena com formas animadas.

Além destes exercícios, os exercícios com máscaras são estruturantes para o trabalho do ator. Existem inclusive lendas que associam a ela o nascimento do teatro. Enfim, não se pode negar o poder desse objeto, seja para o teatro ou fora dele.

Dessa forma, faz-se fundamental fazer algumas observações sobre o uso de máscaras ${ }^{8}$ como procedimento. Abro então um parêntese para indicar a sua utilização, apresentando as primeiras instruções que costumo dar aos participantes: não pensar a máscara como artifício nem como vetor, mas como conduto ou elo; escutar a materialidade da máscara, o que ela tem a dizer, dialogando com ela ou a subvertendo.

No final de alguns exercícios com vários tipos de máscaras e material que cumpram essa função, eu pergunto: Usou bem a máscara ou foi ela que te usou? Faço a pergunta sem almejar respostas; responde quem acha que tem a resposta. Além disso, eu quase sempre dizia: "O silêncio anda de mãos dadas com a palavra". "A máscara não vê nada

\footnotetext{
${ }^{6}$ Um exercício que também se utiliza de bonecos com nós, mas com perspectivas diferentes, foi o realizado na oficina A Lógica do Movimento, ministrada por Stephen Mottram, durante o Festival Internacional de Teatro de Animação - FITA FLORIPA, em 2015.

7 Comportamento de coro se refere à dinâmica do Coro Corifeu, no qual um "rege" o início da ação e os demais acompanham "fazendo coro".

${ }^{8}$ Antes de qualquer exercício com máscara, é preciso contextualizar que esse objeto nasceu no ritual e devido a essa origem, ela tem por excelência uma predisposição de acessar questões metafísicas. Assim sendo, essa característica tão forte e ancestral que a conecta com os planos material e espiritual não deve ser ignorada. Por isso, é sugerido que o início do uso da máscara deve ter como indicativo um movimento mais lento, e com isso, mais desenhado.
} 
além de outra máscara ou o público". Esta era uma questão que se aproximava da triangulação e obrigava os atores a ter movimentos precisos, devido ao olhar estar sempre tentando tocar um objeto ou "quebrar a parede". O olhar não ficava solto do espaço, mas sempre tentando encontrar algo. A máscara liga, quase sempre, dois mundos, os quais precisam ser descobertos por eles.

*Construindo um corpo para a Máscara9 - Esse exercício tem várias funções, mas destaco a função do observador ser o propositor de uma partitura corporal para outro corpo compor uma expressão para a máscara. Pede-se aos participantes para sentarem no chão em semicírculo, e em seguida, solicita-se um voluntário. Este deve se posicionar de frente para os demais participantes no meio do semicírculo e com os olhos fechados. De dentro de uma sacola ou enrolada em um tecido, tira-se uma máscara, que não pode ter sido vista por ninguém até então, e coloco-a no rosto da pessoa que está no centro. A partir desse momento ela pode abrir os olhos, não conhecendo a expressão da máscara, que pode ser neutra ou expressiva.

Os demais participantes devem dar orientações de comportamentos corporais, sem descrever sensações ou sentimentos, apenas indicando como os membros devem se posicionar. Por exemplo: pernas levemente flexionadas, barriga para frente, quadril para trás, braços estendidos para cima, uma mão na cabeça e outra na axila etc. Também pode-se orientar para deslocamentos: caminhe colocando mais peso no ombro direito fazendo um movimento circular com o quadril, etc.

Os participantes, em algum momento, podem bater uma palma, que deve imediatamente atrair o olhar da máscara. Essa atração pode desencadear uma interação do mascarado com quem bateu a palma, uma interação moderada, por meio do olhar, suspiros, podendo haver, no máximo, um leve toque, pois o canal principal de comunicação nessa interação deve ser foco.

Esse exercício é de uma potência incrível para o entendimento prático da construção corporal como fator fundamental e modificante na expressão da máscara. Isso se deve ao propositor da partitura corporal (participante que observa) estar fora do objeto máscara, entendendo o conjunto da composição: um corpo que preenche uma máscara; que deve dar sentido a ela, mesmo quando ela já for uma máscara expressiva. Esse ângulo, da construção de um corpo para máscara, dá ao propositor uma qualidade analítica, possibilitando uma visão externa dessa relação, ao ponto de que quando ele for ocupar essa ou outra máscara, ele terá essa perspectiva como referência.

Na medida em que o exercício avança, pode-se sugerir composições corporais ambíguas com a máscara, estabelecendo algumas transgressões nessa imagem corpórea do ator com ela.

${ }^{9}$ O primeiro contato com uma versão desse exercício foi na oficina A Lógica do Movimento, ministrada por Stephen Mottram, durante o Festival Internacional de Teatro de Animação - FITA FLORIPA, em 2015. 


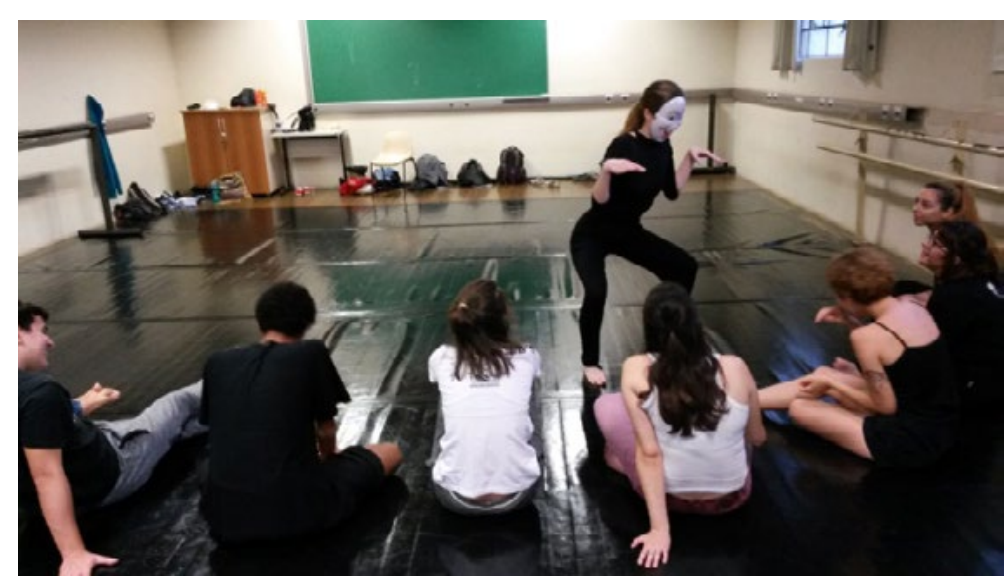

Bonecos de nós. Foto: Fábio H. Nunes Medeiros

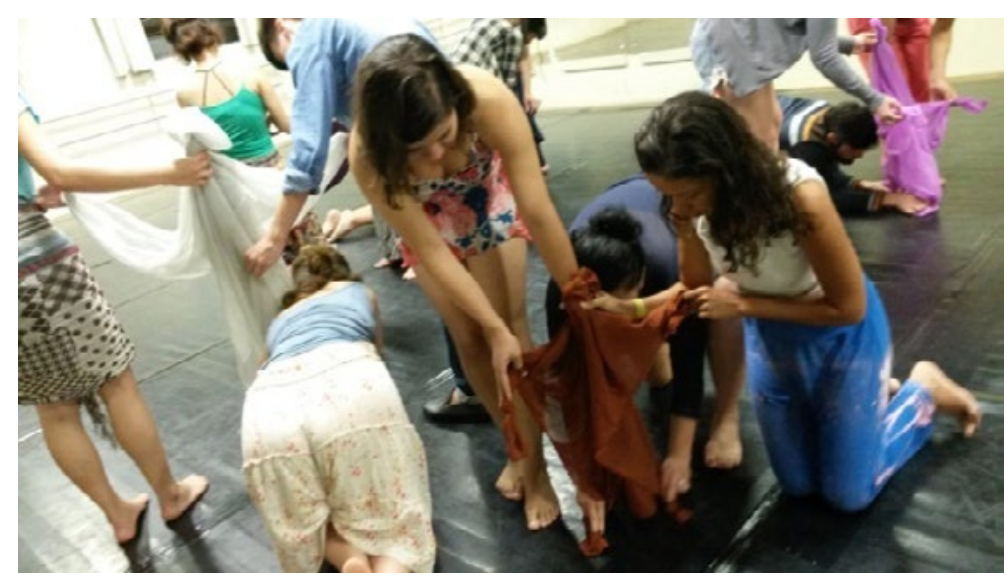

Construindo um corpo. Foto: Fábio H. Nunes Medeiros

* Máscaras Baús - É uma espécie de exercício de adivinhação com máscaras, no qual há escritas dentro de cada máscara algumas palavras ou frases, de modo que somente o portador de cada uma sabe o que está escrito. Sem falar nada, a pessoa que pegou a máscara a coloca no rosto e deve tentar com o seu corpo dizer o que tem dentro da máscara para o público, que por sua vez deve adivinhar para libertar a pessoa daquela máscara. As palavras não podem ser fáceis, devendo ser quase criptogramas e frases metafóricas. Então, os participantes usuários das máscaras devem eleger um significado que achem que representa a ideia para realização.

* Bonecos ou máscara? - Nesse exercício, coloca-se uma quantidade de bolas

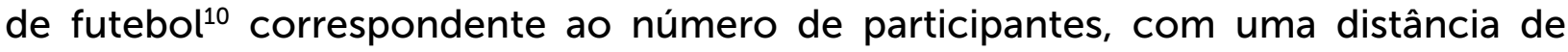
aproximadamente três metros entre cada participante e a bola. A quantidade de participantes deve ser, por vez, no mínimo dois e no máximo quatro. Num plano frontal eles ficam de costas para as bolas e, preferencialmente, de frente para uma parede. Num comando, todos viram e andam em direção às bolas, olhando para elas. Durante esta trajetória, seus corpos devem buscar uma caminhada que represente um personagem. Esse corpo, no primeiro momento, deve seguir um arquétipo. Ao chegar até as bolas que se encontram no chão, todos abaixam para pegá-las. Nesse momento, eles podem optar por colocar na frente do rosto ou na altura de um boneco. Essa ação determinará as seguintes.

\footnotetext{
${ }^{10}$ Numa segunda rodada do exercício, as bolas podem ser substituídas por máscaras, cabeças de bonecos ou as suas próprias mãos, assim o foco poderá ficar melhor definido.
} 
Caso optarem por fazer da bola uma máscara, aquele corpo deve continuar seguindo a partitura proposta na caminhada e o foco deve estar na bola, que deve olhar para as outras figuras-bolas, ou para o público. E caso optarem pelo boneco, a bola será a cabeça do mesmo, tendo que transferir para o boneco a partitura corporal da caminhada, considerando que o boneco-de-apenas-cabeça deve ter eixo e foco, e o manipulador, foco e neutralidade.

Após algum tempo do desenvolvimento da ação, é dado o comando de "mudar", para que haja a inversão de posições entre bonecos e máscaras. É preciso alertar que a transição entre eles não pode ser abrupta, mas que faça parte de uma composição cênica.

Há ainda outras variações desse exercício, podendo-se inserir sons ou a interação entre os personagens, sejam eles máscaras ou bonecos.

Por fim, para se entender essa estrutura de representação, é fundamental que se faça uso dos códigos dessa linguagem, servindo-se da manipulação deles numa composição estética. Ou seja, a combinação da percepção e da representação são os condutos para a composição.

\section{Composição (linguagem, elaboração poética)}

Experimentação prática - (construção de formas e proposições técnicas e estéticas). Esse eixo tem como diretriz a elaboração de procedimentos que culminem num discurso artístico. É um exercício puro de linguagem, mas sob a diretriz de procedimentos pré-elaborados. Todos os participantes irão fazer proposições que resultem numa cena ou num procedimento de treinamento que almeje o desenvolvimento de algum aspecto para o grupo, servindo assim para um discurso ou tema que se pretenda abordar.

Entre os procedimentos, é possível que seja adotada uma "fórmula" clássica de criação em teatro de animação, considerando sua matriz com a sintaxe plástica, quando se possibilita a alternativa da "fórmula": Do material para a ação teatral ou da ação teatral para o material, movimento este que rege muitas formas de fazer teatro de animação.

Contudo, como mencionado, essa fase é de criação, tanto de novas proposições quanto de apropriações e adaptações dos procedimentos metodológicos.

Anotações do processo de montagem: Autômatos - Self da inexistência11

Quando vocês escolheram o simulacro, vocês romperam com a palavra. Um homem sem sombra ou um homem de areia, uma mulher de pedra ou pixel, não tem vida. Na morte simbólica estão todas as mortes. ${ }^{12}$

\footnotetext{
${ }^{11}$ A peça estreou em de 07 de abril de 2018 no TELAB - Teatro Laboratório da FAP-UNESPAR, durante o Festival de Teatro de Curitiba. Produzida pela Cia Laica, que contou com o apoio institucional da FAP - Faculdade de Artes do Paraná da UNESPAR, por meio dos seguintes grupos: Grupo de pesquisa Campo de Visão: formação do espectador-artista-professor de Teatro coordenado pelo profo Robson Rosseto; Projeto de Extensão Poéticas Tridimensionais coordenado pelos Profs. Flávio Marinho e Lorena Barolo Fernandes; e LABIC - laboratório de iluminação cênica coordenado pela profa Nadia Moroz Luciani.

12 Trecho da peça Autômatos - Self da Inexistência, escrita por Fábio H. Nunes Medeiros.
} 
Por fim, para exemplificar o uso dessa proposição, agora em um processo de montagem que se utilizou dela quase como metalinguagem, expondo procedimentos, destaco algumas dessas utilizações no processo de montagem do espetáculo Autômatos - Self da inexistência.

Autômatos é um espetáculo cheio de referências literárias, filosóficas, cotidianas e práticas, sobre a vida líquida, quando o humano se desfaz em várias fases de liquidez. É sobre a ausência de tudo e excesso do nada, sobre um olhar perdido que abraça o vazio e busca a inexistência sem nem saber o que se busca. Num discurso que instala a ambiguidade entre autonomia e automatização, quando a existência se transforma numa metáfora indecifrável. Tem como tema central a automatização e a efemeridade das relações humanas. Num tempo em que se é consumido por uma iminente angústia de não poder estar em todos os eventos de modo que o desejo de ter um duplo se materializa. O espetáculo fala sobre a degradação humana, da linguagem. Ao ponto que as figuras, "personagens", vão perdendo a linguagem (Site: Cia Laica)

O processo de montagem teve como premissa investigar uma série de procedimentos que contemplam o OLHAR como elemento de linguagem. Assim sendo, experimentamos o "Campo de Visão" de Marcelo Lazzaratto, bem como alguns princípios do teatro de animação e exercícios que enfatizam o olhar. Esses recursos foram investigados e desenvolvidos no processo como principal elemento motriz para a construção dramatúrgica, entendendo dramaturgia como aquilo que organiza a emergência de signos da ação teatral. Esse entendimento é fundamental para reconhecer que a dramaturgia do espetáculo, bem como o processo, entende que a encenação se faz pela sintaxe verbal, visual e sonora.

Muitos recursos que contemplam o olhar e o foco foram trazidos não apenas como procedimentos artísticos para o treinamento, mas especialmente como um discurso estético em si, pois o ato e o efeito de olhar, nessa montagem, eram um dos núcleos centrais do tema, embora isso não tenha sido tratado de forma retórica na peça, mas por meios de analogias na dramaturgia, especialmente pela dramaturgia visual. Deste modo, o treinamento dos atores, bem como toda a visualidade, tinha que dar conta de "contar", sem palavras, esse grande tema que não estava explícito no texto.

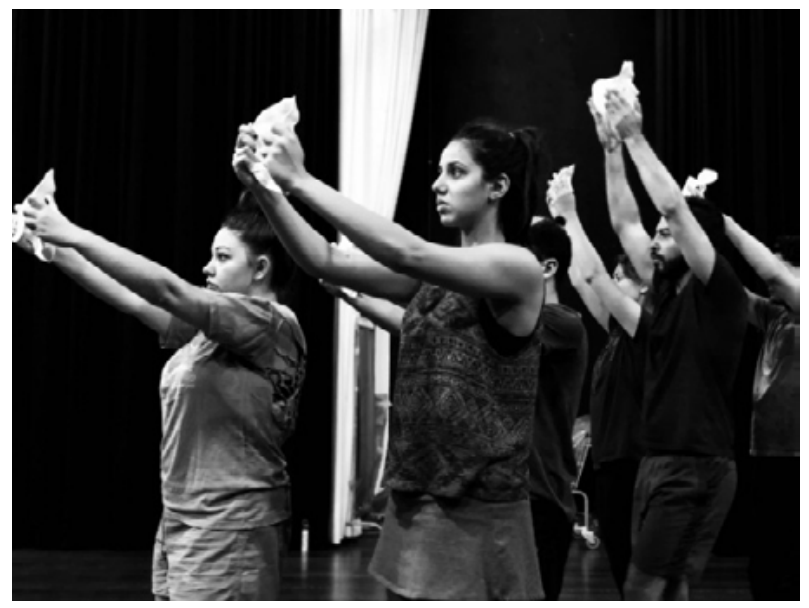

Ensaio. Foto: Jade Giaxa 


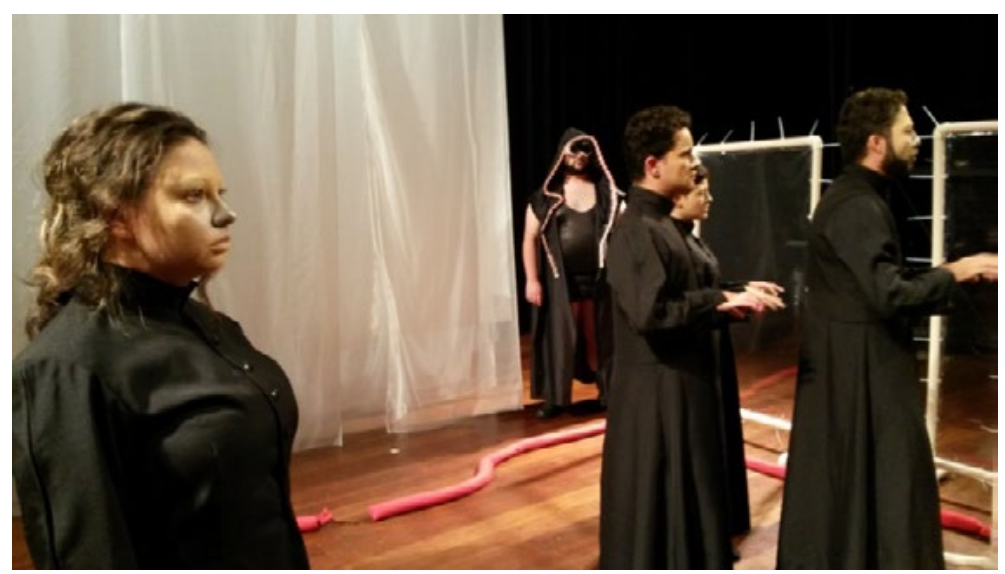

Ensaio. Foto: Fábio H. Nunes Medeiros

Muitos exercícios de foco e de olhar, triangulação, associados a uma variação do Campo de Visão e exercícios de "coro" foram realizados e adaptados. Muitas questões foram demolidas, inclusive de princípios do uso de máscaras, justamente porque estávamos investigando uma poética do olhar, e por isso havíamos recorrido a esses dois grandes recursos: um conjunto de exercício sobre olhar do princípio do teatro de animação e o Campo de Visão.

A escolha do tema e do recurso do olhar como motivo estético tinha um propósito muito bem delineado, devido a um entendimento do olhar como uma forte característica humana, além de um dos principais veículos de comunicação. $O$ poder da comunicação visual está na sua operacionalidade que funciona quase como uma língua universal. Mas nossa questão não era a busca por um espectador universal, e sim a utilização do olhar como um importante indicativo de vida e de ausência dela. Por isso, a arte de animação tem como um de seus objetos o estudo sobre o olhar, e como se almejava que os personagens tivessem vidas falsas, recorremos a uma investigação profunda sobre o olhar.

Ficamos quase três meses imbricando uma série de exercícios para o olhar, o que gerou um processo silencioso dos atores, criando uma angústia generalizada. Essa foi uma das consequências de se debruçar numa espécie de linguagem do olhar, surgindo muitas dúvidas em relação ao "produto", a peça, uma vez que esse era o interesse de todos.

É importante mencionar que para o desenvolvimento temático e pedagógico-teatral recorreu-se a textos de trabalho, mas que corriam quase que numa via paralela. As fontes iniciais de estudos textuais foram os livros Vida Líquida, de Zygmunt Bauman e Sociedade Excitada: filosofia da sensação, de Christoph Türcke, além de três contos: "O Homem de Areia" e "Autômatos", de Ernst Theodor Amadeus Hoffmann, e "A Sombra", de Hans Christian Andersen.

Todavia, todos os textos que tínhamos como fonte inicial foram cada vez mais se afastando no processo, até que, quando considerei que existia naqueles corpos, e especialmente naqueles olhares, uma contradição de morte-vida, de ausência-presença, considerei que tínhamos uma identidade visual-dramática estampada naquelas figuras. A partir daí, retomamos alguns textos e chamamos a preparadora 
corporal para dar continuidade àquela célula. Os atores passavam a ser a síntese do drama sem nenhum subterfúgio retórico. Eu disse para os atores: "pronto, é isso, esse corpo rejuntará tudo que vier pela frente, não esqueçam deles".

Embora fontes literárias tenham sido utilizadas como referência no processo, pouco era possível reconhecê-las no trabalho final, uma vez que elas tiveram uma função muito mais subjetiva do que direta para a dramaturgia final. Isto se deve ao fato de que Autômatos consiste em um espetáculo polifônico e intertextual, excitado por um estado de inúmeros atravessamentos, pensamentos e ausências.

Assim, a "dramaturgia" foi se construindo a partir de ícones, com situações condensadas que pareciam se fechar em si como pequenos monólogos egoístas, mas que se interligavam pelo fator temático, da massificação, da perda de identidade, da escolha pelo simulacro em detrimento do real, entre outras questões, aludindo à linguagem da informação computadorizada. Para isso, a encenação explorou todos os elementos da linguagem teatral, dando, assim, suporte à linearidade do enredo que parecia fragmentado. Além disso, a estrutura narrativa se utilizou também de alegorias, com o mesmo propósito.

Contudo, embora estas ideias estivessem claras na minha cabeça, não estavam para os atores, que manifestavam confiança, mas também angústias. E o processo se deu todo deste modo, parecido com a montagem de um filme, em que os atores faziam as cenas "às cegas", e eu as ia montando, criando assim um repertório visual que só podia ser visto desse ângulo externo. Um outro exemplo dessa "cegueira" foi o fato da não materialidade; uma vez que havia poucos objetos para os ensaios, eles tinham, basicamente, que interagir com o invisível, até o dia da estreia. Deste modo, os artistas que estavam fora da cena começaram a ter uma visão mais coesa da dramaturgia do que os próprios atores que a executavam, pois estes, embora tivessem uma compreensão interna do que dizia a cena, não podiam ver a materialidade e o conjunto do sentido que aquilo produziria dentro da dramaturgia. Nesse sentido, todo o trabalho de treinamento da percepção para a animação deu suporte para essa manipulação do invisível.

Um outro fator que remete a vários processos de montagem e que é fundamental para ajudar a compreender a dinâmica da dramaturgia da imagem é observar também as minhas tentativas frustradas ao se realizar um processo colaborativo. Esta é uma experiência muito pessoal, mas pelo número de recorrências, me faz pensar que os modos operantes da dramaturgia da imagem pressupõem a necessidade da figura do diretor, ou melhor, do encenador como o maestro da organização e, também, principal propositor desses códigos. Contudo, esta é uma impressão que merece ainda passar pelo crivo do laboratório, mas que trago aqui como registro de um procedimento já experimentado nessa e outras montagens.

Digamos, então, que a dramaturgia da peça estabelece uma conversa fenomenológica com os textos, pois ela fica num nível subjetivo nas formas de apropriação, indo ao encontro da essencialidade do que queríamos dizer, muito mais do que da sua forma. Assim, mesmo que no texto apareçam citações diretas em determinadas cenas, elas não concluem o enredo original, servindo assim de motivo para se encontrar uma imagem gerada por tal enredo. A dramaturgia na encenação foi, então, se engendrando para nós como uma dramaturgia "aberta", o que me faz pensar que quando assim for, 
a encenação deve ser "fechada". Ou seja, mais objetiva, já que tratávamos a imagem como organizadora da significação, muito mais do que o texto verbal.

Obviamente, não temos poder sobre a produção de sentido que cada espectador terá sobre nossas "narrativas". Entretanto, quanto mais "aberto" for o código, maiores serão as multiplicidades de leitura. Portanto, para que a experiência do espectador não fique tão abstrata, e consigamos "contar uma história", é necessário que a encenação seja coesa e que o enunciado tenha uma sequência. Deste modo, novamente se retoma a estrutura do referente.

Assim, em razão desta linguagem híbrida, a montagem não se enquadra diretamente em nenhum gênero literário ou da linguagem teatral, devido fortemente também ao seu fator temático, além de ter se optado por uma estética que buscava experimentar a dramaturgia da imagem associada à linguagem do teatro de animação, e de um modo que não se estabelecesse uma hierarquia entre os códigos.
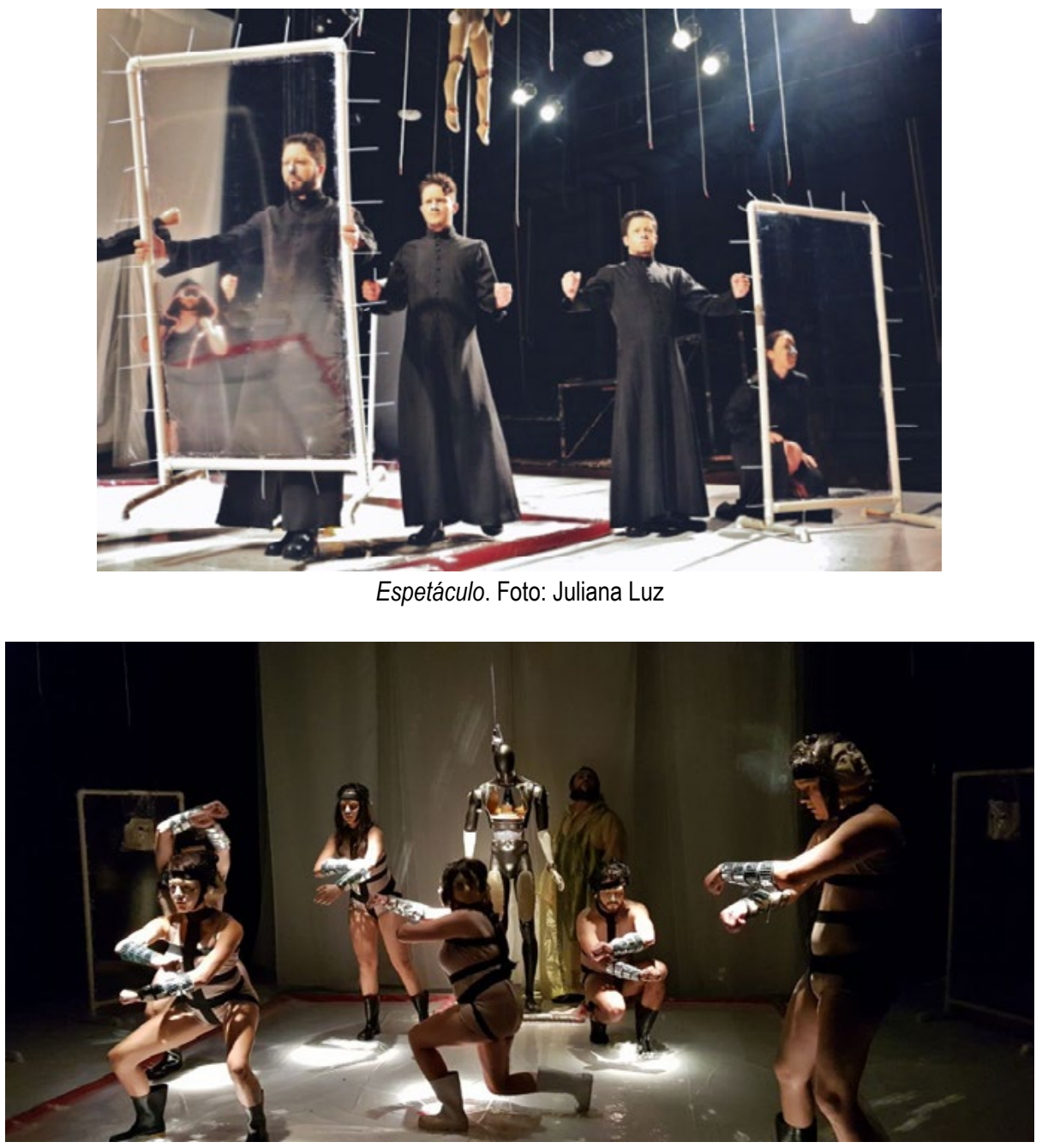

Espetáculo. Foto: Janilson Pacheco

Assim, ao se observar o espetáculo, considerando isso a soma do processo com o "produto" em encontro com o público, pode-se dizer que tínhamos nele um olhar "narrativo", um olhar que tinha condensado passado, presente e futuro, e tinha um discurso. Um olhar que tinha um drama, e que o corpo dava suporte para esse olhar tão elaborado para o cumprimento dessa função, determinante para a encenação. Então se pode dizer que tínhamos uma dramaturgia do olhar, retomando aqui o entendimento sobre dramaturgia como aquilo que organiza a escritura cênica. 


\section{Considerações}

Essa proposição, aplicada em dois ambientes díspares, mas nem tanto, serve para revelar, também, a identidade estética da encenação. Em muitos desses procedimentos aparece uma percepção, bem como traços estéticos de manuseio da linguagem do teatro de animação, que vão se desenhando muito pelo conteúdo e pela forma. Contudo, isso não é uma predeterminação, mas um movimento natural que acontece em vários períodos, em escolas e no seio de vários grupos.

Para mim, o discurso do olhar arrematava tudo com o que mais me identifico no teatro de animação e, consequentemente, na dramaturgia da imagem. Ele foi o recurso que nos possibilitou várias contradições: inanimado-animado, presença-ausência, vida-morte, personagem-ator-performer, narração-sensação, concreto-abstrato, real-fantástico, ilusão-realidade, movimento-estático, etc. Não se levou a cabo esse interesse pelas contradições literalmente no sentido de forças antagônicas, mas no sentido de forças ambíguas, que servem a um dos primeiros movimentos da construção da metáfora, pois a contradição por si já gera metáfora.

Essa minha percepção vem, talvez, da literatura e das artes plásticas, mas não dos gêneros literários dramáticos ou narrativos, e sim da poesia. E no que se refere às artes visuais, possivelmente venha do exercício de composição de objetos num determinado espaço, além da atribuição das qualidades dramáticas e narrativas à sintaxe plástica, percebendo-a com suas especificidades, além de suas inter-relações com o verbal e o sonoro. Essa característica revela que a construção das imagens para a cena vem imbuída de uma enorme carga de poesia, de modo que essa construção tem muito mais como fim a metáfora do que a comunicação. A metáfora quase sempre recorre à própria metáfora. Quando o signo é complexo, ele potencializa a multiplicação de outros signos.

No percurso dessas reflexões, falamos de dramaturgia da imagem, "dramaturgia aberta" e "dramaturgia do olhar". Qualquer que seja a matriz, pressupõe-se o domínio da lógica de composição, da harmonia ou do caos, mas que culmine em um discurso estético.

Por fim, se juntarmos essa proposição e o processo de montagem da peça Autômatos - Self da inexistência, podemos perceber que são métodos da mesma linhagem. Nada era mais importante no espetáculo do que o olhar enquanto discurso. Isto serve para dizer que a dramaturgia visual, corporal, sonora, espacial, entre outras formas discursivas, estão subordinadas a "o que dizer". Ou seja, a dramaturgia se comporta como uma metodologia de escritura da cena.

Muito além disso, todas essas definições serão completadas ou concluídas na produção de sentido do espectador, aquele que de fato organiza a danação de coisas que o artista produz. É quando o evento teatral encontra seu acabamento.

\section{Referências}

AMARAL, A. Maria. Teatro de formas animadas. 3aed. São Paulo: EDUSP - Editora da Universidade de São Paulo, 1996. 
BOAL, Augusto. Jogos para atores e não-atores. 14르ed. Rio de Janeiro: Civilização Brasileira, 1998.

JURKOWSKI, Henryk. Metamorphoses - La Marionnetteau XX Siécle. Trad.: Eliane Lisboa. Charleville-Mézières (França): Éditions InstitutInternational de la Marionnette, 2000.

LAZZARATTO, Marcelo. Campo de Visão- Exercício e linguagem cênica. São Paulo: Escola Superior de Artes Célia Helena, 2011.

LECOC, Jacques. Corpo Poético: uma pedagogia da criação cênica. [trad. Marcelo Gomes]. São Paulo: Editora SENAC São Paulo: Edições SESC SP, 2010.

SANCHEZ, José A. M. Dramaturgias de la Imagen. 3a ed. Cuenca: Ediciones de la Univesidad de Castilla-la Mancha. 2002.

SANTAELLA, Lúcia. Matrizes da linguagem e do pensamento: sonora, visual e verbal. 3a ed. São Paulo: Iluminuras, 2005. 